\title{
Molecular identification of Cryptosporidium baileyi in Muscovy ducks (Cairina moschata domesticus) in free-range production systems
}

\author{
Lidiane Tavares Duarte Berriel ${ }^{1}$ Adriana Pittella Sudré ${ }^{\circledR}$ \\ Helena Lúcia Carneiro Santos $^{3}$ (D) Teresa Cristina Bergamo do Bomfim ${ }^{1 *}$ (D)
}

1Departamento de Parasitologia, Instituto de Veterinária, Universidade Federal Rural do Rio de Janeiro (UFRRJ), 23890-000, Seropédica, RJ, Brasil. E-mail: tcbb@ufrrj.br. "Corresponding author.

${ }^{2}$ Departamento de Microbiologia e Parasitologia, Instituto Biomédico, Universidade Federal Fluminense (UFF), Niterói, RJ, Brasil.

${ }^{3}$ Instituto Oswaldo Cruz, Laboratório de Estudos Integrados em Protozoologia, Rio de Janeiro, RJ, Brasil.

\begin{abstract}
Cryptosporidiosis is considered an infection with impact on animal health. It has been associated with high morbidity and mortality rates, leading to significant economic losses to the poultry industry. This study investigated the presence of Cryptosporidium spp. in domestic ducks of family Anatidae (Cairina moschata) from two rustic commercial aviaries located in the city of Rio de Janeiro, Brazil. A total of 315 fecal samples were collected from domestic ducks in two different areas $(N=186$ in area A and N=129 in area B). The microscopic analysis was conducted using a sugar centrifugal flotation technique for the identification of Cryptosporidium spp. oocysts, followed by PCR/ sequencing analyses of the partial sequence of the $18 S \mathrm{rDNA}$ gene to determine the Cryptosporidium species. Of the 315 samples collected, only 10 (186/5.38\%) from area A were positive for Cryptosporidium. The nucleotide sequence and phylogenetic analyses identified that all samples were identical (100\%) and belonged to Cryptosporidium baileyi species, which is closely related to gastric species and of importance in animal health.
\end{abstract}

Key words: muscovy ducks, protozoan, molecular analysis, Cryptosporidium baileyi.

Identificação molecular de Cryptosporidium baileyi em patos Muscovy

(Cairina moschata domesticus) em sistemas de produção ao ar livre

RESUMO: Criptosporidiose é considerada uma infeção com impacto na saúde animal. Tem sido associada a altas taxas de morbidade e mortalidade, levando a perdas econômicas significativas para a indústria avícola. Este estudo teve como objetivo investigar a presença de Cryptosporidium spp. em patos domésticos da familia Anatidae (Cairina moschata) de dois aviários comerciais rústicos localizados na cidade do Rio de Janeiro, Brasil. Um total de 315 amostras fecais foram coletadas de patos domésticos em duas áreas (Área A / $n=186 ;$ Area B / $n=$ 129). Amostras fecais foram processadas e utilizando a técnica de centrífuga e flutuação em solução saturada de açúcar para a identificação de oocistos de Cryptosporidium spp. através da observação microscópica. Naquelas amostras positivas, procedeu-se com o diagnóstico molecular para determinação de espécie de Cryptosporidium. Das 315 amostras coletadas, apenas 10 (186/5,38\%) da área A foram positivas para Cryptosporidium. A sequência de nucleotídeos e as análises filogenéticas identificaram que todas as amostras eram idênticas (100\%) e pertenciam à espécie Cryptosporidium baileyi, intimamente relacionada às espécies gástricas e de importância na saúde animal.

Palavras-chave: patos-almiscarados, protozoário, análise molecular, Cryptosporidium baileyi.

\section{INTRODUCTION}

The order Anseriformes, family Anatidae, which comprises birds such as ducks, geese and swans, presents cosmopolitan distribution (FIGUEROLA \& GREEN, 2006). This order comprises birds that are resistant to diseases and of greater robustness than chickens (Gallus gallus), thus requiring less care during breeding and rearing (MEULEN \& DIKKEN, 2003). Cryptosporidiosis is characterized as an emerging problem for the global poultry industry.
It is considered one of the main parasitic infections affecting this class of birds.

There are only five valid species of Cryptosporidium infecting avian hosts, namely, Cryptosporidium meleagridis (SLAVIN, 1955), C. baileyi (CURRENT et al., 1986), C. galli (PAVLASEK, 1999), C. avium (HOLUBOVÁ et al., 2016) and $C$. proventriculi (HOLUBOVÁ et al., 2019), in addition to 13 genotypes of unknown species status: Avian genotypes I-VI, black duck genotype, Eurasian woodcock genotype, and Eurasian goose

Received 01.01.21 Approved 06.22.21 Returned by the author 09.03.21

CR-2021-0001.R3

Editor: Rudi Weiblen (1D) 
genotypes I-V (ABE \& MAKINO, 2010; RYAN et al., 2014; CHELLADURAI et al., 2016).

Cryptosporidium baileyi is considered a generalist parasite species in the avian class, infecting a wide variety of wild birds, as well as birds raised as pets or for production (GOODWIN \& KRABILL, 1989; CHVALA et al., 2006; HUBER et al., 2007; Van ZEELAND et al., 2008; NAKAMURA et al., 2009; WANG et al., 2010; QI et al., 2011; LI et al., 2016). This species has been diagnosed in some countries in poultry production, such as in pheasants in the Czech Republic (MÁCA \& PAVLÁSEK, 2015) and broilers in China (WANG et al, 2014). C. baileyi can establish infection in the epithelial cells of the respiratory tract, causing clinical respiratory disorders in chickens, turkeys, and ducks (CURRENT et al., 1986; RYAN, 2010; GOODWIN et al., 1996; MOLINA-LOPEZ et al.; 2010; WANG et al., 2010). These infections are often associated with high morbidity and mortality, especially in broilers (RYAN, 2010), leading to significant economic losses to the poultry industry (ABBASSI et al., 1999, BLAGBURN et al., 1990, GOODWIN \& BROWN, 1989). In addition to the respiratory tract, $C$. baileyi can also cause infection in the bursa of Fabricius, cloaca and trachea (CURRENT et al., 1986), with the last as the most common site of inflammatory processes and clinical signs. Nevertheless, no effective measures or treatments have been taken or developed to prevent infection by $C$. baileyi to date, which may develop in association with of stress from various causes, with presence of concomitant diseases, as well as several immunodeficiency conditions (SRÉTER \& VARGA, 2000).

Experimental studies addressing the infectivity of C. baileyi and C. galli have demonstrated that susceptibility may vary with age (SRÉTER et al., 1996; SRÉTER \& VARGA, 2000). The age factor associated with natural infection by Cryptosporidium meleagridis and $C$. baileyi have also been verified by LAATAMNA et al., 2017 and HELMY et al., 2017. In contrast, HOLUBOVÁ et al., 2018 experimentally assessed the association between age and host specificity in birds infected with Cryptosporidium avium and reported that the course of infection in ducks did not differ between age groups.

The present study diagnosed by microscopy the presence of Cryptosporidium spp. in domestic ducks of family Anatidae (Cairina moschata domesticus) from two rustic commercial aviaries located in the city of Rio de Janeiro, Brazil. In addition, this study used molecular tools, for genotype characterization, followed by sequencing and phylogenetic analyses, for species identification.

\section{MATERIALS AND METHODS}

\section{Description of the aviaries}

Fecal samples from domestic ducks of family Anatidae (Cairina moschata) were collected in two rustic commercial aviaries, labeled area A and area $\mathrm{B}$. The first is located in the municipality of Paracambi (22॰36'42.62" S; 43॰42'39.67' O) and the latter in the municipality of Seropédica $\left(22^{\circ} 44^{\prime} 38^{\prime \prime} \mathrm{S}\right.$; $43^{\circ} 42^{\prime} 28^{\prime \prime} \mathrm{O}$ ). Figure 1 shows a map with the location of the municipalities where the duck fecal samples were collected. In these two areas, 315 fecal samples were collected: 186 in area A and 129 in area B. After collection, the samples were separated according to the age (days) range of the animals: $\leq 30, \geq 31 \leq 60$, $\geq 61 \leq 120$, and $>60$ days.

Both aviaries used the same breeding system, and the Muscovy ducks were raised free along with other fowl species such as chickens, quails and predominantly, other duck species. In addition to several free-living birds, such as doves and pigeons in search of food and water, dogs and cats were also reported in these aviaries. Regarding the hygiene and sanitary conditions of the facilities, because the birds were raised free, scattered feces were constantly found throughout the breeding environment - not only from ducks, but also from other animals. In area A, in addition to the ducks, chickens (Gallus gallus) were used in egg incubation to increase the hatching rate during the natural breeding phase. Area B employed natural incubation using only ducks, as well as an automatic brooder. Both aviaries were used for subsistence through the sale of live and slaughtered birds and their eggs.

\section{Fecal sample collection and microscopic diagnosis of Cryptosporidium spp.}

Feces collection was performed individually, the birds were placed in sanitized cages, and fresh stools were collected from the bottom and placed in sterile polystyrene containers and transferred in isothermal boxes to the laboratory. Subsequently, the samples were processed and initially analyzed for the presence of oocysts of Cryptosporidium spp. using the centrifugal flotation in saturated sugar solution technique (SHEATHER, 1923). Samples positive for the presence of Cryptosporidium spp. oocysts were preserved under refrigeration for further DNA extraction and subsequent analyses. 


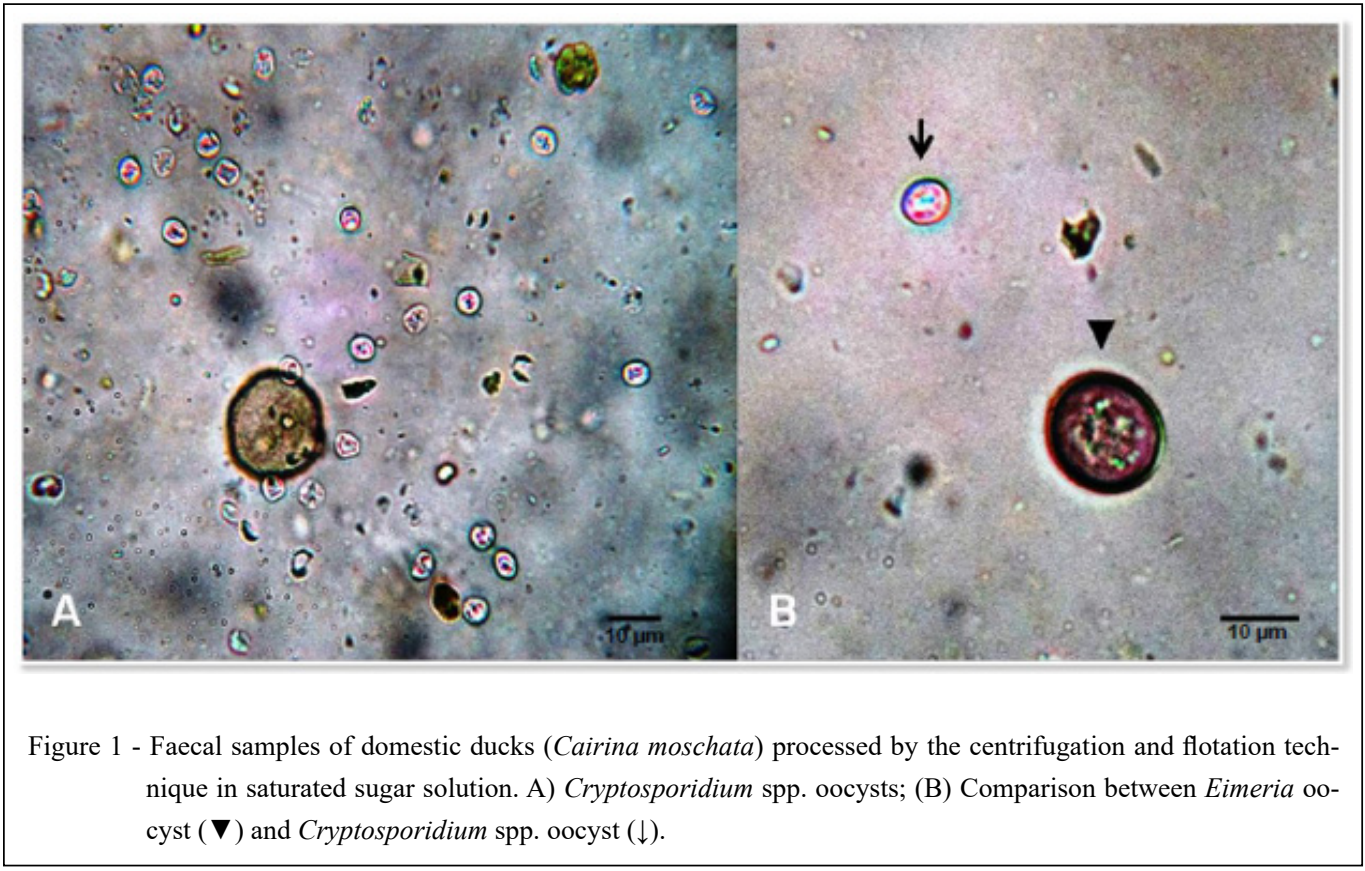

\section{DNA extraction}

Genomic DNA was extracted using the commercial QIAamp Fast DNA Stool Mini Kit (Qiagen GmbH, Hilden, Germany) according to the manufacturer's recommendations, with minor modifications with respect to the two incubation periods of the material, when samples subjected to a temperature of $95^{\circ} \mathrm{C}$ with a longer incubation period (10 $\mathrm{min})$ and using a temperature-controlled stirrer at $800 \mathrm{rpm}$ to assist with sample homogenization. At the end of extraction, the samples were eluted in $100 \mu \mathrm{L}$ of buffer AE (supplied by the manufacturer), instead of in $200 \mu \mathrm{L}$.

\section{PCR and Nested-PCR}

Polymerase chain reaction (PCR) was conducted in two phases, corresponding to the $18 \mathrm{~S}$ rRNA gene of the parasite. The following primers were used in the primary PCR: $18 \mathrm{~S}$ rDNA gene F: 5 - TTC TAG AGC TAA TAC ATG CG-3` (forward) and 18SR: 5 ' CCC ATT TCC TTC GAAACA GGA3 ' (reverse), where amplicon sizes of approximately $1325 \mathrm{pb}$ were obtained (XIAO et al., 1999). The following primers were used in the nested-PCR: 18SNF: 5 - GGA AGG GTT GTA TTT ATT AGA TAA AG-3` (forward) and 18SNR: 5’- AAG GAG TAA GGA ACA ACC TCC A-3` (reverse), where amplicon size ranging from 826 to $864 \mathrm{pb}$ was obtained depending on the Cryptosporidium species and/or genotypes diagnosed (XIAO et al., 1999).

Primary PCR was performed using $4 \mathrm{mM}$ $\mathrm{MgCl}_{2}$ (Invitrogen), $0.2 \mu \mathrm{M}$ of each primer (18SF and 18SR - Invitrogen), 1x Taq buffer (Invitrogen), $200 \mu \mathrm{M}$ of each deoxyribonucleotide (dNTP Invitrogen), $1.0 \mathrm{U}$ of Platinum Taq Polymerase (Invitrogen), $2 \mu \mathrm{L}$ of DNA, and ultra-pure water (Nuclease-free water - Promega) until a reaction volume of $25 \mu \mathrm{L}$ was completed.

Nested-PCR was performed under the same conditions described for the primary PCR but using half the concentration of $\mathrm{MgCl}_{2}(0.2 \mathrm{mM}), 0.2$ $\mu \mathrm{M}$ of primer $18 \mathrm{SNF}$ and $0.2 \mu \mathrm{M}$ of primer 18SNR, $1 \mu \mathrm{L}$ of product from the primary PCR, and ultrapure water (Nuclease-free water - Promega) until a reaction volume of $25 \mu \mathrm{L}$ was achieved.

Thermal cycling for the primary and nestedPCR started at $94{ }^{\circ} \mathrm{C}$ for $3 \mathrm{~min}$ (hot start), followed by 35 cycles of $94^{\circ} \mathrm{C}$ for $45 \mathrm{sec}, 58^{\circ} \mathrm{C}$ (primary-PCR) or $59^{\circ} \mathrm{C}$ (nested-PCR) for $45 \mathrm{sec}$, and $72{ }^{\circ} \mathrm{C}$ for $1 \mathrm{~min}$. At the end of the 35 cycles, a final extension phase was conducted at $72{ }^{\circ} \mathrm{C}$ for $7 \mathrm{~min}$. The products obtained were visualized by electrophoresis on $2 \%$ agarose gel ( $100 \mathrm{~V}$ for $60 \mathrm{~min}$ ) stained with ethidium bromide $(5 \mu \mathrm{g} / \mathrm{mL})$.

All nested-PCR positive products were purified using Exonuclease I/Shrimp and Alkaline Phosphatase (ExoSAP-IT ${ }^{\mathrm{TM}}$ ) (USB Corporation;

Ciência Rural, v.52, n.5, 2022. 
Cleveland, USA) following the manufacturer's instructions. All purified amplicons were sequenced once, both in the forward and reverse directions.

\section{Sequence Alignment and Phylogenetic Analysis}

Analysis of the chromatograms and editing of the sequences were conducted utilizing the SeqMan Pro software (DNASTAR Inc., Madison, WI, USA). Consensus sequences were compared with those previously published in the GenBank database using the BLASTN program from the NCBI server (http:// www.ncbi. nlm.nih.gov/BLAST). In addition, DNA sequences of Cryptosporidium spp. were obtained from GenBank, and multiple sequence alignment was performed using the ClustalW algorithm of the MEGA 6.0 software (TAMURA et al., 2013).

\section{RESULTS}

\section{Microscopic diagnosis of Cryptosporidium spp.}

In this study, after analysis of 315 fecal samples, only animals from area A tested positive for Cryptosporidium spp., with 10 parasitized birds of $186(5,4 \%)$. Table 1 shows the percentages of parasitism according to the age group of the animals. In addition to Cryptosporidium oocysts, some samples also presented Eimeria spp. oocysts (Figure 1).

\section{Molecular diagnostics}

DNA extraction was performed in the samples positive for oocysts of Cryptosporidium spp. After primary and nested PCR were conducted, amplicons with approximately $830 \mathrm{bp}$ were observed, confirming that the region of the target 18S rDNA subunit gene was amplified for Cryptosporidium spp.

Fragments of the sequences obtained from the Cryptosporidium isolates from fecal samples of domestic ducks were compared with the sequences deposited in GenBank and showed $100 \%$ similarity with the Cryptosporidium baileyi sequences of a variety of hosts of the bird class and geographic locations: KY012352 (DA CUNHA et al., 2017, Brazil, Anser cygnoides); KF994570 (PRYSTAJECKY et al., 2014, Canada, surface water); JX548294 (WANG et al., 2014, China, Gallus gallus); GQ426096 (BOUGIOUKLIS et al., 2013, USA, Falco cherrug); HM002495 (WANG et al., 2010, China, Gallus gallus); GU377276 (WANG et al., 2011, China, Struthio camelus); GQ227474 (NAKAMURA et al., 2009, Brazil, Coragyps atratus); GQ227475 (NAKAMURA et al., 2009, Brazil, Sicalis flaveola); JQ217142 (WANG, et al., 2012, China, Coturnix coturnix japonica); AF262324 (XIAO et al., 2000, USA, isolated from storm waters). The obtained nucleotide sequences were deposited in GenBank under the following access numbers: KY710765, KY710766, and KY710767.

\section{DISCUSSION}

In the present study, only young animals from area A were positive for Cryptosporidium spp. The birds were apparently healthy, and no symptoms associated with infection by Cryptosporidium spp. were observed during stool collection, corroborating the findings by RICHTER et al., 1994 on natural infections by Cryptosporidium spp. in farm-raised

Table 1 - Total number of samples obtained from ducks (Cairina moschata) separated according to age range and site of collection, showing the percentage of parasitism by Cryptosporidium spp.

\begin{tabular}{|c|c|c|c|c|}
\hline \multirow{2}{*}{ Age Group of Animals (days) } & \multicolumn{2}{|c|}{ 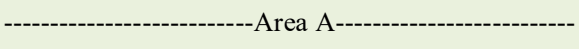 } & \multicolumn{2}{|c|}{ 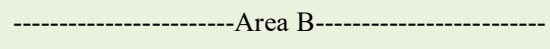 } \\
\hline & $\begin{array}{l}\text { Total Number of } \\
\text { Samples }\end{array}$ & $\begin{array}{l}\text { Parasitological diagnosis of } \\
\text { Cryptosporidium spp. }\end{array}$ & $\begin{array}{l}\text { Total Number of } \\
\text { Samples }\end{array}$ & $\begin{array}{l}\text { Parasitological diagnosis of } \\
\text { Cryptosporidium spp. }\end{array}$ \\
\hline Up to 30 & 60 & $08(13.3 \%)$ & 28 & 0 \\
\hline 31 and 60 & 44 & $02(4.5 \%)$ & 35 & 0 \\
\hline 61 and 120 & 52 & 0 & 40 & 0 \\
\hline More than 121 & 30 & 0 & 26 & 0 \\
\hline Total & 186 & $10(5.4 \%)$ & 129 & 0 \\
\hline
\end{tabular}

Total $($ Local A + B) $=315(3.2 \%)$ 
ducks and geese in a study conducted in Germany. The aforementioned authors reported no correlation between presence of Cryptosporidium and poor animal performance, clinical signs of disease, or gastrointestinal lesions. Similarly, no clinical signs of cryptosporidiosis were reported in the experimental observation of chickens, ducks and pheasants infected with Cryptosporidium avium (HOLUBOVÁ et al, 2018).

In this study, Cryptosporidium baileyi was diagnosed in ducks aged $\leq 30$ and $\geq 31 \leq 60$ days. Age is a determinant of epidemiological risk of infection by Cryptosporidium spp., with evidence reported in some studies conducted with birds. Because Cryptosporidium is an opportunistic pathogen, younger animals are more susceptible to the disease and its possible complications (TƯMOVÁ, 2002). HOLUBOVÁ et al., 2018 experimentally assessed the age and host specificity for Cryptosporidium avium and verified that the course of infection in ducks did not differ between age groups.

In area $A$, it is possible to suggest that other avian species, such as chickens (Gallus gallus) and geese (Anser anser domesticus), that were raised for production together with the ducks could have been infected and consequently, infected the ducks through environmental contamination. However, the possibility of environmental contamination by free-living birds should not be discarded, especially by those of the order Columbiformes, such as doves and pigeons, which were commonly reported in these rustic aviaries in search of water and food.

Free-living birds as possible disseminators of Cryptosporidium oocysts, generating environmental contamination, were previously described by REBOREDO-FERNÁNDEZ et al. (2015), who diagnosed C. meleagridis in turtledoves (Streptopelia turtur). In China, QI et al. (2011) investigated Cryptosporidium spp. in 32 bird species in pet shops, and for the order Columbiformes, $C$. meleagridis was diagnosed in pigeons (Columba livia) and turtledoves (Streptopelia turtur). In contrast, pigeons (Columba livia) interact with wild and domestic birds, as well as with several mammals, including humans, facilitating the dispersion of Cryptosporidium spp. oocysts when they are infected (GRACZYK et al., 2008).

Another possibility for infection with Cryptosporidium in the birds investigated in this study could be associated with the water supplied in the aviaries. It is known that Cryptosporidium is water-borne and infects a wide variety of vertebrate hosts, including humans (FAYER \& XIAO, 2008).
A possible source of infection in area A may have been the use of chickens (Gallus gallus) for incubation of the eggs of the ducks to increase hatching rate during the natural breeding phase; in this way, the ducklings could have become infected after the hatching of the eggs. This fact was mentioned by SCHULZE et al. (2012), who reported that infection with Cryptosporidium baileyi in a group of ducklings (Mergus serrator) in a zoo in Germany could possibly have occurred through the interaction with other species of resistant ducklings that dwelled the same environment, as well as by adult mallard ducks (Anas platyrhynchos) that were used in the incubation of eggs of red-breasted merganser (Mergus serrator) to increase hatching rate during the natural breeding phase.

The natural cross-transmission of Cryptosporidium baileyi has already been documented, this probability of transmission occurs when birds of different species are raised in the same environment (HAMIDINEJAT et al., 2014). In one of the aviaries investigated in this study (area A); although, infection by Cryptosporidium has not been investigated in other species of birds that were raised with domestic ducks, this possibility should not be ruled out as a form of natural cross-transmission for Ducks.

Ducks are a robust avian species, and more resistant to various diseases that affect other birds raised for production. Cryptosporidium has been reported in several species of ducks (RICHTER, et al., 1994; KUHN et al., 2002; HUBER et al., 2007; WANG et al., 2010; GOMES et al., 2012; KALIFA et al., 2016; SHEMSHADI et al., 2017; LAATAMNA et al., 2017, LARKI et al, 2018), and there is a rare record, without characterization of the species, in Muscovy ducks (ZWART, 1987).

Despite the importance of identifying Cryptosporidium species for the understanding of avian cryptosporidiosis epidemiology, there are few studies on the molecular characterization of Cryptosporidium baileyi in different bird species, especially in the order Anseriformes. It is known that the species Cryptosporidium baileyi presents greater occurrence in the class of the birds compared with $C$. meleagridis, being able to infect a larger spectrum of hosts (ZAHEDI et al., 2015).

\section{CONCLUSION}

The importance of determining the various aspects of cryptosporidiosis as an avian disease is undeniable. However, because cryptosporidiosis is a subclinical disease or because it does not present a suggestive clinical condition, this pathology is often 
neglected, but it deserves to be more comprehensively studied in poultry farming because it generates economic losses. This study demonstrated that Muscovy ducks parasitized by Cryptosporidium baileyi may be a source of infection for susceptible birds and deserve further investigation.

\section{ACKNOWLEDGEMENTS}

This study was financed in part by the Coordenação de Aperfeiçoamento de Pessoal de Nível Superior (CAPES) Brasil- Finance Code 001. The first author was funded by CAPES grant / Process N. 1504974.

\section{BIOETHICS AND \\ COMMITTEE APPROVAL}

BIOSSECURITY

This study was conducted according to the norms established by the National Council for the Control of Animal Experimentation (CONCEA), Brazil. The survey was approved by the Ethics Committee on Animal Use of the Veterinary College of the Federal Rural University of Rio de Janeiro (UFRRJ) under protocol no. 6598050617. Permission from the owners of the animals was obtained prior to sample collection. The research did not involve threatened or protected animal species. The research did not involve threatened or protected animal species. The data/ results of the manuscript are not plagiarism and have not been published elsewhere

\section{DECLARATION OF CONFLICT OF INTEREST}

The authors declare that they have no conflict of interest.

\section{AUTHORS' CONTRIBUTIONS}

All authors contributed equally for the conception and writing of the manuscript. All authors critically revised the manuscript and approved of the final version.

\section{REFERENCES}

ABE, N.; MAKINO, I. Multilocus genotypic analysis of Cryptosporidium isolates from cockatiels. Japanese Parasitology Research. V. 106, p.1491-1497, 2010. Available from: <https:// doi: 10.1007/s00436-010-1810-5>. Accessed: Jul. 06, 2020.

BLAGBURN, B.L. et al. Cryptosporidium sp. infection in the proventriculus of an Australian diamond fire tail finch (Staganoplura bella Passeriformes, Estrildidae). Avian Diseases. V. 34, p. 1027-1030, 1990. Available from: <https://www.jstor.org/ stable/1591401>. Accessed: Jul. 06, 2020.

BOUGIOUKLIS, P.A., et al. Otitis media associated with Cryptosporidium baileyi in a saker falcon (Falco cherrug). Journal of Comparative Pathology. V. 148, p. 419-423, 2013. Available from: <https://doi: 10.1016/j.jcpa.2012.09.005>. Accessed: Jul. $06,2020$.

CHELlADURAI, J.J., et al. Cryptosporidium galli and novel Cryptosporidium avian genotype VI in North American red- winged blackbirds (Agelaius phoeniceus). Parasitology Research. V. 115, p. 1901-1906, 2016. Available from: <https://doi: 10.1007/ s00436-016-4930-8>. Accessed: Jul. 06, 2020.

CHVALA, S., et al. Infection in domestic geese (Cryptosporidiu Anser anser $f$. domestica) detected by in-situ hybridization. Journal of Comparative Pathology. V. 134, p. 211-218, 2006. Available from: <http://dx.doi.org/10.1016/j.jcpa.2005.11.002>. Accessed: Jul. 06, 2020.

CURRENT, W. L., et al. The life cycle of Cryptosporidium baileyi n. sp. (Apicomplexa, Cryptosporidiidae) infecting chickens. Journal Protozoology. V. 33, p. 289-96, 1986. Available from: $<$ https://doi.org/10.1111/j.1550-7408.1986.tb05608.x>. Accessed: Jul. 06, 2020.

DA CUNHA, M. J. R., et al. Molecular identification of Enterocytozoon bieneusi, Cryptosporidium, and Giardia in Brazilian captive birds. Parasitology Research. V. 116(2), 487-493, 2017. Available from: <https://link.springer.com/ article/10.1007/s00436-016-5309-6>. Accessed: Jul. 06, 2020.

FAYER, R.; XIAO, L. Cryptosporidium and cryptosporidiosis, 2nd edn. CRC Press, Taylor \& Francis Group, Boca Raton, 2008. 560 p.

FIGUEROLA, J.; GREEN, A, J. A comparative study of egg mass and clutch size in the Anseriformes. Journal of Ornithology. V. 147, p. 57-68, 2006. Available from: <https:// doi: 10.1007/s10336005-0017-5>. Accessed: Jul. 06, 2020.

GOMES, R.S., et al. Cryptosporidium spp. parasitize exotic birds that are commercialized in markets, commercial aviaries, and pet shops. Parasitology research. V. 110, p. 1363-1370, 2012. Available from: <https://link.springer.com/article/10.1007\%2 Fs00436-011-2636-5>. Jul. 06, 2020.

GOODWIN, M.A., et al. Respiratory coccidiosis (Cryptosporidium baileyi) among northern Georgia broilers in one company. Avian Diseases. V. 40, p.572-575, 1996. Available from: http://dx.doi. org/10.2307/1592266>. Accessed: Jul. 06, 2020.

GOODWIN, M.A.; BROWN, J. Intestinal cryptosporidiosis in chickens. Avian Diseases. V. 33, p. 770-777, 1989. Available from: $<$ http://dx.doi.org/10.2307/1591159>. Accessed: Jul. 06, 2020.

GOODWIN, M.A.; KRABILL, V.A., Diarrhea associated with small-intestinal cryptosporidiosis in a budgerigar and in a cockatiel. Avian Diseases. V. 33, p.829-833. 1989. Available from: $<$ https:// doi: 10.2307/1591170>. Accessed: Jul. 06, 2020.

GRACZYK, T.K, et al. The role of birds in dissemination of human waterborne enteropathogens. Trends Parasitology. V. 24, p. 5559, 2008. Available from: <https://doi: 10.1016/j.pt.2007.10.007>. Accessed: Jul. 06, 2020.

HAMIDINEJAT, H., et al. Molecular determination and genotyping of Cryptosporidium spp. in fecal and respiratory samples of industrial poultry in Iran. Asia Pacific Journal Tropical Medicine. V.7, p. 517-20, 2014. Available from: <https://doi. org/10.1016/S1995-7645(14)60086-9>. Accessed: Jul. 06, 2020.

HELMY, Y.A., et al. Molecular diagnosis and characterization of Cryptosporidium spp. in turkeys and chickens in Germany reveals evidence for previously undetected parasite species. Plos One. V.2, p. 1-12, 2017. Available from: <https://doi.org/10.1371/ journal.pone.0177150>. Accessed: Jul. 06, 2020. 
HOLUBOVÁ, N., et al. Host specificity and age-dependent resistance to Cryptosporidium avium infection in chickens, ducks and pheasants. Experimental Parasitolology. V. 191, p. 62-65, 2018. Available from: <https://doi.org/10.1016/j. exppara.2018.06.007>. Accessed: Jul. 06, 2020.

HOLUBOVÁ, N., et al. Cryptosporidium avium n. sp. (Apicomplexa: Cryptosporidiidae) in birds. Parasitology Research. V.115, p. 2243-51, 2016. Available from: <https://doi: 10.1007/s00436-016-4967-8>. Accessed: Jul. 06, 2020.

HOLUBOVÁ, N., et al. Cryptosporidium proventriculi sp. n. (Apicomplexa: Cryptosporidiidae) in Psittaciformes birds. European Journal of Protistology. V. 69, p.70-87, 2019. Available from: <https://doi.org/10.1016/j.ejop.2019.03.001>. Accessed: Jul. 06, 2020.

HUBER, F., et al. Genotypic characterization and phylogenetic analysis of Cryptosporidium sp. from domestic animals in Brazil. Veterinary Parasitology. V. 150, p. 165-174, 2007. Available from: <https://doi.org/10.1016/j.vetpar.2007.08.018>. Accessed: Jul. 06, 2020.

KALIFA, M.M., et al. Cryptosporidium species in ducks: parasitological, serological and molecular studies in Egypt. International Journal of Advanced Research in Biological Sciences. V. 3(3), 23-31. 2016. Available from: <https://s-o-i. org/1.15/ijarbs-2016-3-3-4>. Accessed: Jul. 06, 2020.

KUHN, R.C., et al. Occurrence of Cryptosporidium and Giardia in wild ducks along the Rio Grande River Valley in Southern New Mexico. Applied Environmental Microbiology. V.68, p.161165, 2002. Available from: <https://doi:10.1128/AEM.68.1.161165.2002>. Accessed: Jul. 06, 2020.

LAATAMNA, A.E., et al. Cryptosporidium meleagridis and $C$. baileyi (Apicomplexa) in domestic and wild birds in Algeria. Folia Parasitologica. V. 64, p. 018, 2017. Available from: <https://doi: 10.14411/fp.2017.018>. Accessed: Jul. 06, 2020.

LARKI, S., et al. A Preliminary survey on Gastrointestinal Parasites of Domestic Ducks in Ahvaz, Southwest Iran. Iranian Journal of Parasitology. V.13, p. 137-144, 2018. Available from: <http://ijpa. tums.ac.ir>. Accessed: Jul. 06, 2020.

LI, Q., et al. Molecular investigation of Cryptosporidium in Small Caged Pets in Northeast China: Host Specificity and Zoonotic Implications. Parasitology Research. V. 115, p. 2905-291, 2016. Available from: <https://link.springer.com/content/pdf/10.1007/ s00436-016-5076-4.pdf >. Accessed: Jul. 06, 2020.

MÁCA, O.; PAVLÁSEK, I. First finding of spontaneous infections with Cryptosporidium baileyi and C. meleagridis in the red-legged partridge Alectoris rufa from an aviary in the Czech Republic. Veterinary Parasitology. V. 209, p. 164-168, 2015. Available from: < https://doi.org/10.1016/j.vetpar.2015.03.003>. Accessed: Jul. 06, 2020.

MEULEN, C.J., DIKKEN, G., 2003. Criação de patos nas regiões tropicais. Agrodok 33. Wageningen: Fundação Agromisa, 2003. 96 p. Available from: <https://docplayer.com.br/14665059-Agrodok-33criacao-de-patos-nas-regioes-tropicais.html >. Accessed: Jul. 06, 2020.

MOLINA-LOPEZ, R. A., et al. Cryptosporidium baileyi infection associated with an outbreak of ocular and respiratory disease in otus owls (Otus scops) in a rehabilitation center. Avian
Pathology. V. 39, p. 171-6, 2010. Available from: $<$ https://doi. org/10.1080/03079451003717589>. Accessed: Jul. 06, 2020.

NAKAMURA, A.A., et al. Molecular characterization of Cryptosporidium spp. from fecal samples of birds kept in captivity in Brazil. Veterinary Parasitology. V. 166, p. 47-51, 2009. Available from: <https://doi: 10.1016/j.vetpar.2009.07.033>. Accessed: Jul. 06, 2020

PAVLÁSEK, I. Cryptosporidia: Biology, diagnosis, host spectrum, specificity, and the environment. Remedia Klinická Mikrobiologie. V.3, p. 290-301, 1999.

PRYSTAJECKY, N., et al. Assessment of Giardia and Cryptosporidium spp. as a microbial source Tracking Tool for Surface Water: Application in a Mixed-Watershed. Appl. Environ. Microbiol. V. 80, p.2328-2336, 2014. Available from: <https:// www.ncbi.nlm.nih.gov/pmc/articles/PMC3993175/pdf/zam2328. pdf $>$. Accessed: Jul. 06, 2019.

QI, M., et al. Cryptosporidium spp. in pet birds: genetic diversity and potential public health significance. Experimental Parasitology. V.128, p. 336-340, 2011. Available from: <https:// doi.org/10.1016/j.exppara.2011.04.003>. Accessed: Jul. 06, 2019.

REBOREDO-FERNÁNDEZ, A., et al. Occurrence of Giardia and Cryptosporidium in wild birds in Galicia (Northwest Spain). Parasitology. V. 142, p. 917-25, 2015. Available from: <https:// doi.org/10.1017/S0031182015000049>. Accessed: Jul. 06, 2019.

RICHTER, D., et al. Natural infections by Cryptosporidium sp. in farm-raised ducks and geese. Avian Pathology. V. 23, p. 277-286, 1994. Available from: <https://doi. org/10.1080/03079459408418995>. Accessed: Jul. 06, 2019.

RYAN, U., et al. Cryptosporidium species in humans and animals: current understanding and research needs. Parasitology. V. 141, p. 1667-85, 2014. Available from: <https://doi.org/10.1017/ S0031182014001085>. Accessed: Jul. 06, 2019.

RYAN, U.M. Cryptosporidium in birds, fish and amphibians. Experimental Parasitology. V. 124, p. 113-120, 2010. Available from: <https://doi.org/10.1016/j.exppara.2009.02.002>. Accessed: Jul. 06, 2020

SCHULZE, C., et al. Cryptosporidium baileyi-infection in Redbreasted Merganser (Mergus serrator) ducklings from a zoological garden. Berliner und Münchener tierärztliche Wochenschrift. V. 125, p. 428-431, 2012. Available from: <https://doi.10.2376/00059366-125-428>. Accessed: Jul. 06, 2020.

SHEATHER, A.L., The detection of intestinal protozoa and mange parasites by a floatation technique. Journal of Comparative Pathology and Therapeutics. V. 36, p. 266-275, 1923.

Available from: <https://doi.org/10.1016/S0368-1742(23)800169>. Accessed: Jul. 06, 2020.

SHEMSHADI, B., et al. Prevalence and intensity of parasitic infection in domestic ducks (Anas platyrhynchas) in Gilan Province, Northern Iran. Comparative Clinical Pathology. V. 26, p. 165-167, 2017. Available from: <https://doi: 10.1007/s00580016-2361-7>.Accessed: Jul. 06, 2020.

SLAVIN, D., 1955. Cryptosporidium meleagridis (sp. nov.). Journal of Comparative Pathology. 65(3), 262-266. Available from: $<$ https:// doi.org/10.1016/S0368-1742(55)80025-2>. Accessed: Jul. 06, 2020. 
SRÉTER, T., et al. Effects of bursectomy and thymectomy on the development of resistance to Cryptosporidium baileyi in chickens. Parasitology Research. V.82, p. 174-177, 1996. Available from: $<$ https://link.springer.com/article/10.1007/s004360050090>. Accessed: Jul. 06, 2020.

SRÉTER, T.; VARGA, I. Cryptosporidiosis in birds - A review. Veterinary Parasitology. V. 87, p. 261-279, 2000. Available from: $<$ https://doi.org/10.1016/S0304-4017(99)00178-8>. Accessed: Jul. $06,2020$.

TAMURA, K., et al. MEGA6: Molecular evolutionary Genetics Analysis Version 6.0. Molecular Biology and Evolution. V. 30, p. 2725-2729, 2013. Available from: <https://doi.org/10.1093/ molbev/mst197 >. Accessed: Jul. 06, 2020.

TƯMOVÁ, E., et al. Performance and oocyst shedding in broiler Chickens orally Infected with Cryptosporidium baileyi and Cryptosporidium meleagridis. Avian Diseases. V. 43, p. 203-207, 2002. Available from: <https://doi.org/10.1637/00052086(2002)046[0203:PAOSIB]2.0.CO;2>. Accessed: Jul. 06, 2020.

Van ZEELAND, Y. R., et al. Upper respiratory tract infection caused by Cryptosporidium baileyi in three mixed-bred falcons (Falco rusticolus x Falco cherrug). Avian Diseases. V. 52, p. $357-$ 63, 2008. Available from: <https://doi.org/10.1637/8121-100207Case.1>. Accessed: Jul. 06, 2020.

WANG, L., et al. Cryptosporidiosis in broiler chickens in Zhejiang Province, China: molecular characterization of oocysts detected in fecal samples. Parasite. V. 21, p. 36, 2014. Available from: $<$ https://doi:10.1051/parasite/2014035>. Accessed: Jul. 06, 2020.

WANG, R., et al. Survey of Cryptosporidium spp. in chickens and Pekin ducks (Anas platyrhynchos) in Henan, China: prevalence and molecular characterization. Avian Pathology.
V. 39, p. 447-451, 2010. Available from: <https://doi: 10.1080/03079457.2010.518314>. Accessed: Jul. 06, 2020.

WANG, R., et al. Prevalence of Cryptosporidium baileyi in ostriches (Struthio camelus) in Zhengzhou, China. Veterinary Parasitology. V. 175, p. 151-154, 2011. Available from: <https:// doi: 10.1016/j.vetpar.2010.10.005>. Accessed: Jul. 06, 2020.

WANG, R., et al. Cryptosporidium spp. in quails (Coturnix coturnix japonica) in Henan, China: Molecular characterization and public health significance. Veterinary Parasitology. V. 187, p. 534-537, 2012. Available from: <https://doi: 10.1016/j.vetpar.2012.02.002>. Accessed: Jul. 06, 2020.

XIAO, L., et al. Identification of species and sources of Cryptosporidium oocysts in storm waters with a small-subunit rRNAbased diagnostic and genotyping tool. Applied and Environmental Microbiology. V. 66, p. 5492-5498, 2000. Available from: <https:// doi: 10.1128/AEM.66.12.5492-5498.2000>. Accessed: Jul. 06, 2020.

XIAO, L., et al. Genetic diversity within Cryptosporidium parvum and related Cryptosporidium species. Applied and Environmental Microbiology. V. 65, p. 3386-33918, 1999. Available from: $<$ https://journals.asm.org/doi/epub/10.1128/AEM.65.8.33863391.1999>. Accessed: Jul. 06, 2020.

ZAHEDI, A., et al. Public health significance of zoonotic Cryptosporidium species in wildlife: Critical insights into better drinking water management. International Journal for Parasitology: Parasites and Wildlife. V. 5, p. 88-109, 2015. Available from: <https://doi:10.1016/j.ijppaw.2015.12.001>. Accessed: Jul. 06, 2020.

ZWART, P., 1987. Cryptosporidiosis in Muscovy ducks (Cairina moschata). In: Erkrankungen der Zootiere, Verhandlungsbericht. 29. Internationalen Symposiums, Cardiff, United Kingdom - UK. 61-64. 